\title{
The Concept of Manas in Jaina Philosophy
}

\author{
Jayandra Soni ${ }^{1}$
}

Published online: 31 January 2020

(C) The Author(s) 2020

\begin{abstract}
The first time Umāsvāti uses the word manas in his Tattvārtha-sūtra (TAS), the standard work for matters concerning Jaina philosophy, is when he lists the means of knowledge: mati, śruta, avadhi, manah-paryāya and kevala (TAS 1, 9). These are the pramannas (TAS 1,10). In TAS 1,14 mati or sense perception is said to be caused by indriya and aninindriya; Pūjyapāda's commentary says that anindriya, antah-karana and manas are synonyms. This obviously raises questions about the specific role and function of the manas/anindriya in mati, manah-paryāya and śruta, and how these retain their exclusivity without reducing the function of any of them to another means of cognition. In the Sānkhya system manas is seen as both an organ of cognition (buddhindriya) and an organ of action (karmendriya, SK 27). It is interesting for a better understanding of the role of manas in Jaina thought to compare some aspects of it with the Sānkhya system.
\end{abstract}

Keywords manas · Jaina epistemology · Umāsvāti's Tattvārtha-sūtra . mati $\cdot$ manah-paryāya $\cdot$ śruta $\cdot$ Sānkhya

The concept of the manas in Jaina philosophy has hardly been a topic of independent study. ${ }^{1}$ Its specific role is acknowledged in Jaina epistemology as is evident in Umāsvāti's Tattvārtha-sütra (TAS), the standard work for matters concerning Jaina philosophy. He uses the word manas quite early in his text, the first

\footnotetext{
${ }^{1}$ See e.g., Kalghatgi (1991), Kobayashi (2010) and Soni (1991). This article is based on the paper presented at the World Sanskrit Conference, Vancouver 9-13 July 2018 in Section 11: Jaina Studies. The word manas is usually translated as the 'mind'.
}

Jayandra Soni

soni@staff.uni-marburg.de;

jayandra.soni@uibk.ac.at

1 Department of Philosophy, Innsbruck University, Innrain 52d, Innsbruck 6020, Austria 
time when he lists the means of cognition or knowledge, jūāna (TAS 1, 9): mati (sense perception), śruta (scriptural or authoritative source of knowledge), avadhi (clairvoyance), manah-paryaya (telepathy or communicating without the use of the senses, also written manah-paryāya), and kevala (omniscience). For our purposes we can ignore two of them: avadhi-jñāna, because it is a special case occurring in celestial and infernal beings (TAS 1,21/22), ${ }^{2}$ and kevala-jñanna, because it occurs in kevalins, namely those who have overcome the influence of karmas and know things as they really are. We shall also not delve in detail into the actual function of manah-paryaya itself either, because it presupposes an advanced stage of asceticism, one that is not affected by the karma that usually hinders the function of manah-paryāya in ordinary individuals. ${ }^{3}$ Here I am interested in the category of the manas itself. We need to note that the first two, mati and śruta, are indirect means (parokșa) and the rest are direct (pratyakșa) means of cognition or knowledge (TAS 1, 11-12), a point that will soon be relevant. We shall see below that according to TAS 1, 14 mati-jñanna is caused (nimitta) by both the indriyas (sense organs) and the anindriya/manas (non-sense-organ). It is mati-jñanna that will chiefly occupy our deliberations here regarding the role of the manas, more than the other means of cognition.

That the manas is a crucial term is evident not only through the epistemological role it plays for example in mati-jñāna (see TAS 1, 13-14 below) and independently as manah-paryaya, but also because of its role in human activity as such. TAS 6, 12 say that together with actions of the body and speech ( $k \bar{a} y a$ and $v \bar{a} k$ ), the action of the manas as well is responsible for the association or connection (yoga) with the jivva of fine, invisible, material pudgala-particles which then operate as karma. This is the Jaina metaphysical category of influx, assrava, in TAS 1, 4 caused by the threefold activity of the body, speech and manas mentioned in TAS 6, 1-2.

Before proceeding with the role of the manas in Jaina epistemology, which is the prime reason for the concern here, it might be useful to recall some fundamental facts in Jainism about the term manas. For a basic orientation regarding the concept itself and its role, it is helpful to look at the terms pudgala, aṇu or paramānu and varganā/vaggana $\bar{a}$, to see how manas is directly related to them.

The term pudgala is usually translated as 'matter' or 'material atom' (Jaini 1979, p. 81). Jaini (1979, p. 101) gives its etymology as traditionally "derived from pum (joining) plus -gala (breaking)". A few related sūtras by Umāsvāti furnish a general idea regarding matter as such, pudgala, and how the manas is a form of it, together with how aṇu or paramānu (atom) is directly concerned with pudgala.

TAS 5, 5/4: rüpinah pudgalăh, "Things which have form constitute matter (pudgalas). ${ }^{5}$

\footnotetext{
${ }^{2}$ The number after the slash refers to the Śvetāmbara version of the TAS which in some cases is different from the Digambara version. See Tatia (1994) for both versions.

${ }^{3}$ See TAS 1, 23-24/24-25 and their commentaries. See also the article by Wiley (2003) for a concise overview of these.

${ }^{4}$ TAS 6, 1: kāya-vāni-manah-karma yogah | TAS 6, 2: sa āsravah । See Soni (2016) for details.

5 All TAS translations based on Jain (1960).
} 
TAS 5, 10: saìkyeyāsaṅkyeyāś ca pudgalānām, "(The space-points [pradeśas]) of forms of matter are both numerable and innumerable". 6

5, 11: nānoh (na aṇoh). Not for the atom (which has space points, pradeśa).

5, 19: śarīra-van்-manah-prān̄āpānāh pudgalānām. "(The function) of pudgalas (is to form the basis) of the body, the organs of speech, the manas and respiration."

5, 20: sukha-duhkha-jivita-maranopagrahāśs ca. "(The function of pudgalas is) also to contribute to pleasure, suffering, life and death of living beings."

5, 25: anavah skandhās ca. Atoms and molecules (are the two main divisions of matter). ${ }^{7}$

5, 26: bheda-sanghātebhya utpadyante "They (the molecules) are formed by division (fission) and union (fusion) and division-cum-union." ${ }^{8}$ Evidently quoting this TAS 5, 26 Jaini (1979, p. 101) summarises how the Jainas envision the formation and destruction of matter (pudgala), namely "through atomic aggregation (samghāta) and disjunction (bheda)".

TAS 5, 28: bheda-sañghātābhyām cākșușah, "(Molecules produced) by the combined action of division (fission) and union (fusion) can be perceived by the eyes".

This random selection of sütras describes matter and its role or functions. For our immediate purposes we need to note 5, 19 above, because manas is singled out as one of the categories formed out of matter or pudgala and how the terms anu or paramānu feature there, namely as a "division" of matter $(5,25)$, together with molecules. In continuing with the basic understanding regarding the manas, we now need to briefly look at the technical term varganāa/vaggaña (Sanskrit/Prakrit) of which the manas forms one such group.

The term vargaṇā/vaggaṇā, is translated as a "group" (Tatia 1951, p. 65). ${ }^{10}$ The 5th part of the Satkhandāgama ${ }^{11}$ is about vargañă/vaggaña in which four anuyogadvāra sections (sparśa, karma, prakrti and bandha) are discussed, namely topics of discussion dealt with in the text. The term therefore seems to be used in the sense of

\footnotetext{
${ }^{6}$ TAS 5,8 is also relevant here: sankkhyeyāh pradeśāh dharmādharmaika-eka-jīvānām, "There are innumerable points of space in the medium of motion, the medium of rest and in each individual jiva".

8 The last part of the translation is taken from the SS commentary to the sütra which says that the "plural is used to include the third, namely, the combined process of division and union" (bahuvacana-nirdeśas tritaya-sañgrahārthah), see also Jain (1960, p. 154). The Śvetāmbara version reads: sañghāta-bhedebhya utpadyante, see Tatia (1994, p. 134). Umāsvāti's commentary also speaks of three causes (kāraṇa) whereas Pūjyapāda uses the word nimitta (SS commentary to TAS 5, 26 §76, line 2).

9 Tatia (1994, p. 134) translates TAS 5, 28 as: "The visibility of the clusters is produced by the combination of disintegration and integration". This probably means that the clusters of molecules which are visible arise through a disintegration and integration of these molecules. See below for the conjecture that Umāsvāti seems to summarise his sanghāta and bheda from the discussion in the ȘkhĀ, vol. 14, sütras 5, 6, 98-116 (pp. 133-223, including the commentary).

${ }^{10}$ For vaggaṇā see also ĀvN 29 (in Leumann p. 7, line 4) and Bhagavaī 1, 19-22, , 14, 79. Reference from Oberlies (1993, p. 142). He notes vaggaṇā as a "term[inus]. tech[nicus]". His entry reads: (JSkt. vārgaṇā-) "catégorie, classe, division / Klasse, Gruppe / category, class, division".

11 The 'Scripture in Six Parts' is an important Digambara canonical work. See Jaini (1979, p. 51) and also Dundas (2002, pp. 63-65) for interesting details about the discovery of this second century work discovered not long before it was published in 16 volumes between 1896 and 1922.
} 
a division in separate exposition-groups of the anuyoga-dvāras. ${ }^{12}$ In sūtras 5, 6, 98116 (vol. 14, pp. 133-223, including the commentary), the Șkh $\bar{A}$ enters into a debate over the terms sainghāta and bheda (Pr. samghāda and bheda) of pudgalaatoms. In sütras 5, 6, 728-756 of the ȘkhĀ (pp. 546-556, vol. 14) a list of five vaggaṇās/varganās is briefly mentioned, in which the manas is mentioned. These are called: $\bar{a} h \bar{a} r a-t e y \bar{a}-$, bhās $\bar{a}-$, mana- and kammaiya-davva-vagganā, namely the dravya-vargaṇās respectively called āhāra, taijasa, bhāṣā, manas (mano-) and kārmaṇa, from which 23 further types are derived. ${ }^{13}$

Since I am concerned only with the manas, as a 'group', we can look at the four kinds of the manas-substance, mana-davva-vaggana, given in ȘkhA 5, 6, 750-751 (vol. 14, pp. 551-552), so that it is clear that the manas is a form of matter and that it directly affects the nature of the sentient principle, jūva. The sütras about the manas group of matter are:

maṇa-davva-vaggaṇā cau-vvihassa maṇassa gahaṇam pavattadi $\| \operatorname{Ṣh} \overline{\mathrm{A}} 5,6$, $750 \|$

sacca-maṇassa moṣa-maṇassa sacca-moṣa-maṇassa asacca-moṣa-maṇassa jāṇi davvāṇi ghettūṇa sacca-maṇattāe moṣa-maṇattāe sacca-moṣa-maṇattāe asacca-moṣa-maṇattāe parịnāmedūṇa parịnamaṇti jūvā tāṇi davvāṇi maṇadavva-vaggaṇā ṇāma \| ȘkhĀ 5, 6, 751 ॥

The text says that the group of pudgala-atoms that makes up the manas is "active" and becomes transformed into four types of manas: true or pure, deceptive, a combination of both and a combination of an untrue and deceptive manas. These forms of manas cause the sentient principle (jiva) to be transformed accordingly in the sense that the jiv $v a$ is obstructed by the form that a particular group of the manas substance (mana-davva-vagganāa/mano-varganāa) takes on, positively in a pure way or negatively in a deceptive manner, with their respective combinations. This description of the role of manas is relevant not only in the context of its role in ethical conduct but also in the context of epistemology in which the manas plays a significant function, as we shall see below.

The conclusion we can draw from the Șkh $\bar{A}$ discussion on varganāalvaggana $\bar{a}$ is that the technical term itself, but not the idea behind it, was abandoned by Umāsvāti in his TAS, perhaps for the sake of brevity so as not to have to discuss in any detail

\footnotetext{
12 See under Pușpadanta and Bhūtabali, vols 14-15.

13 The groups, varganās/vagganās, refer to what is constituted of atoms and molecules of pudgala and the space-points (pradeśa) they occupy. See Tatia (1951, p. 65) for a description of how the groups are formed and pp. 65-69 for manah-paryāya-jñāna, including how this is distinguished from avadhi-jñāna. See also Varn̄ī (1990) for a summary of 23 varganās derived from the basic five types, vol 3, p. 515. As for kärmana-varganā in the SS, Jain (1960) mentions it in his index, p. 294 as "molecules of karma matter which fill the universe" and refers to TAS 8, 24/25, but the word neither occurs in the sütra nor in the SS commentary. Although the idea of a group is carried over, Umāsvāti avoids the word varganāa. See further below. The basic 5 types of vargaṇās are distinct from the 5 types of bodies (śarīrāni) in TAS 2, 3637.

A debate has arisen about the antiquity of he $S \mathrm{kh} \bar{A}$ in comparison with the fourth Śvetāmbara upāinga, the Prajñāpanā-sütra (Pannavanāa-suttam). Whatever the final outcome of the ongoing debate about which text is earlier (see Soni 2015, p. 133), it might be of interest to know that judging from the entries of the term varganāa/vagganā in the index to the upāinga-text, there does not seem to be such an exposition of vargaṇa as in the ȘkhĀ. See s.v. vol. 9 of the Mahāvīra Jaina Vidyālaya edition, in two parts, the Paṇnavaṇā-suttam (Prajñāpanā-sūtra).
} 
the vast theme of the numerous groups of matter. Umāsvāti took over the idea of a group of atoms that join one another or disjoin (TAS 5, 26 above), omitting the explicit term varganāa/vagganāa, retaining only the idea of sanghāta and bheda. The topic of vargañä/vaggaṇa is interesting in itself, but our concern is only with the manas as a group of matter, particularly in the epistemological role it plays in Jainism and especially with reference largely to one of the five pramannas in Jainism, and briefly mentioning the two other means of cognition: mati (sense perception), śruta (scriptural or authoritative source of knowledge), manah-paryaya (telepathy or communicating without the use of the senses, also written manah-paryāya). As already pointed out, we are omitting the remaining means mentioned in TAS 1, 9 avadhi (clairvoyance) and kevala (omniscience) for the reasons already mentioned. Up to this point we have now seen how the concept manas fits into the structure of pudgalas as a specific group. Let us now proceed to the role of the manas in our cognition.

Cognition is a speedy, split-second, complex procedure involving our entire psycho-somatic structure and the Sānkhya system gives a clear presentation of it, which we have learnt early in our studies in Indian philosophy. In Sānkhya, cognition through the senses is a process that involves the roles of buddhi, ahainkāra, manas and the indriyas, where the manas has the unique status of being both a buddhindriya as well as a karmendriya (SK 26-27). ${ }^{14}$ It is generally taught that the role of the manas is indispensable in the cognition process, playing an important intermediary function between the external sense organs (the eyes, ears, etc.) and the outer world of objects observed through the indriyas or external senses, resulting in the final judgement about the object, that the object of perception is this or that thing. 'With the split-second speed of thought' (manovegena) manas passes on the data provided by the sense-organs to the buddhi which then makes the final judgement that the object is this or that thing. It is known that in Sānkhya manas is an evolute of prakrti or matter as such.

We saw that the Jainas also see manas as matter, which they call pudgala. However, whereas Sānkhya has a system of 24 categories which makes up its ontology and metaphysics, Jainism has just the two ontological categories (dravya) of jiv $a$ and ajiv va, with the latter being a generic term standing for pudgala, dharma, adharma, àkāśa and kāla. These two, jīva and aj̄̄va, constitute the basis on which Jainism builds up its metaphysics, adding to these two the five well-known concepts of āsrava, bandha, samvara, nirjarā and mokșa (TAS 1, 4). To compare the unique status of manas as both buddhindriya and karmendriya in Sānkhya with manas in Jainism, is quite instructive because it reveals interesting insights and differences, as we shall see below when we briefly mention the point concerning an advanced state ascetic discipline. Moreover, in the epistemological context, Sānkhya accepts only three pramāṇas (drșța, anumāna and āpta-vacana, SK 4) whereas Jainism has a different classification of two pramānas (parokșa and pratyakșa), the first comprising mati and śruta, and the latter avadhi, manah-paryaya and kevala,

\footnotetext{
${ }^{14}$ buddīndriyāṇi cakșuh śrotra-ghrāṇa-rasana-tvag-ākhyāni I vāk-pāṇi-pāda-pāyūpasthān karmendriyāny āhụ̣ || SK 26 || ubhayātmakam atra manaḥ sañkalpakam indriyam ca sādharmyāt I guna-pariṇāmaviśeșān nānātvam bāhya-bhedāś ca || SK 27 ॥
} 
making up five in all. It is interesting that mati, sense perception, is regarded as parokșa, namely as being indirect, whereas in Sānkhya it is a direct form of cognition. Let us look at some details concerning mati-jñana and the role of manas in it.

\section{Mati-jñāna}

In dealing with the concept of manas in Jainism we are compelled to become more precise in our concern with Jaina epistemology. Usually mati-jñāna is simply regarded as sense perception, without distinguishing not only the perception of sight from the others (touch, taste, smell and hearing), but also ignoring the four stages involved in the process of mati-jñāna (avagraha, īhā, avāya/apāya and dhārañā, TAS 1, 15). This is noteworthy because the avagraha stage of mati-jñana does not apply to sight (and the manas), as we shall see immediately. Let us recall that mati, and śruta, are indirect means of cognition and in the case of sense perception, the Jainas draw a perceptive distinction between sight and the other sense-organ perceptions. The significance of this for us is that for the Jainas the functions of sight and the manas have to be treated separately.

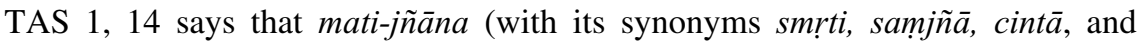
abhinibodha, supplied in TAS 1,13) is caused by the indriyas (sense organs) and the anindriya (non-sense-organ). ${ }^{15}$ A part of Pūjyapāda's commentary on this is directly relevant here. He says that anindriya, antah-karana and manas are synonyms. ${ }^{16} \mathrm{He}$ adds that the negative particle (nañ) in anindriya is used in the sense of $\bar{\imath}$ at , meaning that the anindriya is not a 'complete' indriya as the external senses are, but somehow like them, a sort of indriya, a crypto-sense-organ. Further, this anindriya or manas is not dependent on the indriyas: "because it is not seen externally, like the eyes, etc, and because it is independent of the indriyas in investigating thoughts of qualities and faults, and for memory, etc., the internal instrument is said to be antah-karana." ${ }^{17}$ Hence, manas has some sort of independence and uniqueness.

Not only is this a clear statement about anindriya, antah-karana and manas being synonymous, and a key one at that, but it is obviously from the specific Jaina perspective: it hints at the independence of the category of manas, apart from alluding to the particular role it is given in its changed, functional mode as a specific instrument of knowledge or cognition, namely as manah-paryaya (telepathy or communicating without the use of the external senses, the eyes, etc.). This independence of manas is not of the Vaiśeșika type where the manas and the atman are listed as two of the nine dravyas in VS $1,5 .{ }^{18}$ In Jainism manas would be a part

\footnotetext{
15 TAS 1, 14: tad [mati-jñānam]-indriyānindriya-nimittam.

16 SS on TAS 1, 14, § 186: anindriyam manah antah-karanam ity anarthāntaram. ... ị̣ad-arthasya nañah prayogāt. īṣad-indriyam anindriyam iti.

17 SS on TAS 1, 14, § 187: guna-doṣa-vicāara-smaran̄ādi-vyāpareșu indriyānapekșatvāc cakșur-ādivad bahir-anupalabdeś ca antar-gatạ karanam antah-karaṇam ity ucyate.

18 Vaiśeșika-sūtra 1, 5: pṛthivy-āpas-tejo vāyur ākāśam kālo dig-ātmā mana iti dravyāṇi.
} 
of ajīva-dravya and a type or group of pudgala, as we have seen, with jīva being the only other dravya that the Jaina tradition accepts.

The SS commentary on TAS 1, 14 reveals an interesting aspect regarding the role of manas. It is said there that the manas is a sign (linga) of the jiv va (here referred to as indra $).{ }^{19}$ Neither the SS commentary nor Umāsvāti's auto-commentary says exactly how the manas operates, only that its function implies the existence of a sentient principle, of which the manas is a sign. As in the case of upayoga,${ }^{20}$ manas is also related to the jiv va, and plays a role as a mass of pudgalas in mati-jñanna, a pramāna that is described as being an indirect means of cognition. Apart from this, the manas plays an independent role in its modified form as manah-paryaya, as an autonomous pramāna, described and functioning now as a direct means of cognition. $^{21}$

So what is the problem? It is in the details. On the one hand, mati arises through the functions of the indriyas and the anindriya (TAS 1, 14) and manah-paryaya arises without the indriyas. Moreover, TAS 1, 19 says that indistinct apprehension (vyañjana/avagraha, see below) does not apply to sight (perception through the eyes) nor to the anindriya/manas (TAS 1, 19: na cakșur-anindriyābhyām). This means that the process of perception through sight is different from the perceptions through the other senses, touch, taste, smell and hearing. One arrives at this position through inference as well (apart from the scriptures), ${ }^{22}$ because the eye 'acts on any object without direct contact with it' (aprāpya-kāri) and because it is not intercepted through contact (sprștānavagrahät). ${ }^{23}$ This statement gives the impression that in contrast to the other senses, the eyes seem to perceive directly, but is in fact not so. Even with the exclusion of one stage in the cognition process, sight being different from the other senses, is still mati-jñāna and, together with śruta, it is regarded as being indirect (parokșa), with the others being direct (TAS 1, 11-12).

\footnotetext{
19 SS on TAS $1,14, \S 186$, last sentence: na tathā manah indrasya lingam api sat-pratiniyata-deśavișayam kālāntarāvasthāyi cal "Even though manas is a 'sign' of indra (=jīva) it does not cognise objects within a limited space nor remain for long" (tr. based on Jain 1960, p. 23).

${ }^{20}$ For upayoga also as a 'sign' (lakșana) of the jīva see Soni (2007, p. 299). TAS 2, 8 says that upayoga is the distinctive characteristic of the sentient principle, $\mathrm{j} \bar{\imath} v a$, namely its 'functions, applications, or faculties' which play a significant role in the cognition process (as jũānopayoga and darśanaopayoga), in which the function of the manas is presupposed.

21 It may be said that the functions of all the sense organs as well indicate the presence of sentience (jiv $a$ ), without whose 'presence' the sense organs cannot fulfil their functions. The point here about manas and upayoga being at the service of jisva seems to be concerned with the subtle and crucial level in the 'final process' of cognition, not with the simple functions of the external senses in this process.

22 In quoting an unidentified scripture in his SS commentary on TAS 1, 19, § 203 to support the view that sight is different from smelling, etc., Pūjyapāda says: āgamatas tāvat "puțtham sunodi saddam apuțtham ceva passade rūam I gaṃdham rasam ca phāsam baddham puṭtham viyānāāi II".

23 SS commentary TAS 1, 19, § 204: yuktiś ca-aprāpya-kāri cakșuh, sprșțānavagrahāt.
} 
In order to better understand TAS 1,19 , just quoted above, we have to look at both TAS 1,18 and 19 together:

TAS 1, 18 vyañjanasyāvagrahah

TAS 1, 19: na cakṣur-anindriyābhyām (as quoted above).

These sütras state that that there is a vyañjana, (an apprehension/sensation of indistinct things, by all the senses), except (only) in the case of the eye and the manas (TAS 1, 19). In order to understand the terms vyañjana and avagraha here we have to look back at TAS 1,15 which provides us with the four stages or divisions, of the process of mati-jñāna (sensory perception):

TAS 1, 15 says: avagrahehāvāya-dhāraṇāh (= avagraha, īhāa, avāya and dhāraṇa ): apprehension or mere sensation, speculation, perceptual judgement and retention (are the four divisions of mati, sense perception).

In other words mati-jñāna is not simply mati-jñāna because, generally, it involves four stages before the object is completely cognised and, in the particular case of sight and the function of manas, these two have a special status because the first avagraha stage of mati-jñāna is short-circuited. Sight and manas, are excluded because the avagraha stage in the process of perception does not take place in them: the stage of apprehension, a mere sensation or an indication that there is an object presented to a respective sense organ, but not yet fully grasped, is excluded in sight and the manas. Cognition as such would occur in fact in the third and fourth stages of avāya (also called apāya) and dhārañă, the final judgement about the object and its retention respectively (the stage of $\bar{\imath} h \bar{a}$ or speculation is not yet perceptual judgement or $a v \bar{a} y a$ ). For this technical reason, the functions of sight and the manas are treated separately from the other sense perceptions.

What would be reason for excluding the avagraha stage in the process of cognition through sight or the manas? How is sight or the manas different from the other four sense perceptions through touch, taste, smell and hearing? The text teaches us that the four, touch, taste, smell and hearing, presuppose a direct contact between the sense-organ and its respective object: wind, etc., has to be in direct contact with the skin to cause a sense of touch, the tongue has to touch something sweet or sour to register taste, a scent or odour has to enter the nose to smell it, and sound waves have to enter the ear in order for us to hear them. This does not seem to be case with the eyes and the mind, nothing has to 'enter' them for the 'sight' of the object looked at, or in investigating thoughts of qualities and faults, or for memory. Hence the stage of avagraha is short-circuited or omitted, so that the eyes and manas directly cognise their respective objects, without the stage of an unspecified object of perception. This is precisely the problem that is being confronted here: mati-jñana (sensory perception) is defined as parokșa-jñanna or indirect perception, so that seems to exclude the eyes (and manas) which has a special status.

The upshot of these deliberations is that we have to distinguish not only between sight and the other organs of perception, but also between it and the role of the manas. Moreover, we have to also distinguish between the manas as such, as group of material particles (varganāa/vaggaña), discussed above, and the manas in its modified form as manah-paryāya which, by definition, is a direct mode of cognition 
(pratyakșa). In other words, the role of the manas-varganā or manas-group in matijūāna (sense perception) makes sense perception indirect (parokșa-jñ̄ana), through the role of the senses, whereas in its modified form as the manah-paryayya means of cognition (telepathy) it is direct (pratyakșa-jñāna) because, as we saw, manahparyāya is a form of communication without the use of the senses. These details are significant in order to uphold the basic Jaina distinction between pratyakșa and parokșa, as already hinted at above when talking about sight and manas. The difference is on account of the role of the senses in perception and their exclusion in the manah-paryāya means of cognition, in terms of Jaina epistemology.

The rest of Pūjyapāda's commentary to TAS 1, 19, § 204 in full verifies what was said above. After sprșțānavagrahāt mentioned above, Pūjyapāda goes on to say there:

yadi prāpya-kāri syāt tvag-indriya-vat sprșțam añjanam gṛhṇ̄yāt, na tu gṛhṇāt yato mano-vad aprāpya-kārīty-avaseyam I tataś cakșur-manasi varjayitvā śeṣānām indriyānā̄m vyañjanāvagrahah । sarveṣām indriyānindriyānāam arthāvagraha iti siddham I

If (the eye) were in contact (with the object) then, like the sense of touch, it would [just as well] perceive the collyrium (añjanam, applied to the eye), but it does not perceive it, so it it to be understood that, like the manas, the eye is a sense without (physical) contact (with the object). Therefore, apart from the eye and manas, the other senses perceive indistinct things (TAS 1, 18 says: vyañjanasyāvagrahah). It is thus established that all the indriyas and the anindriya/manas perceive (their respective) objects [differently). ${ }^{24}$

Umāsvāti's auto-commentary on TAS 1, 19 says:

cakṣuṣā no-indriyeṇa ca vyañjanāvagraho na bhavati I caturbhir-indriyaih śeșair bhavatīty arthah I evam etan mati-jñannam dvi-vidham catur-vidham așta-viṃśati-vidham așta-ṣașasțhyutara-śati-vidhạ̣ șaț-triṃśa-tri-śati ca bhavati I

There is no apprehension of what is indistinct (vyañjana) through the eye and manas. This means that it (an indistinct apprehension) occurs (only) through the remaining four sense organs (touch, taste, smell and hearing). Thus, this mati-jñāna can be twofold, fourfold, twenty-eightfold, one hundred and sixtyeightfold or three hundred and thirty-sixfold. ${ }^{25}$

What the above brief summary concerning the concept of manas has revealed in the case of sense perception or mati-jñanna, is the teaching that the function of sense perception through the eyes (and the manas) is to be seen in a significantly different way from the other four sense perceptions, through touch, taste, smell and hearing. The reason we saw was that according to the Jainas objects known through sight do not 'enter' the eyes, as is the case with the other sense perceptions where a direct

\footnotetext{
${ }^{24}$ The rest of the SS commentary on TAS 1, 19 merely introduces the next sütra.

25 This is the Jaina classification with reference to numbers: twofold would be: indriya and anindriya;

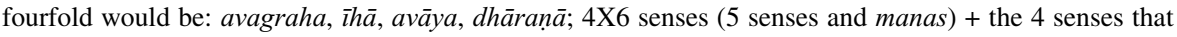
have vyañjanāvagrahah $=28$; etc.
} 
contact with the respective sense organ is necessary: contact with the skin is necessary to cause a sense of touch, the tongue has to touch something sweet or sour to register taste, a scent or odour has to enter the nose to smell it, and sound waves have to enter the ear in order for us to hear them. In other words, we have to separate sight and the manas from the others for the sake of precision when talking about the Jaina theory of knowledge.

\section{Śruta-jñāna}

There has been an age-old debate in the history of Indian epistemology about the exact and independent nature of scriptural or authoritative knowledge, variously referred to as śruti, śabda, apta-vacana, or śruta in Jainism. Those who regard it as a separate, autonomous pramāna, do not relegate it to either sense perception or inference. This holds true even if it is accepted that the function of the eyes and/or ears in reading or hearing serve as an aid. The senses by themselves, however, do not yield the essence of scriptural knowledge any more than the eyes alone by themselves yield the cognition of fire by seeing only the smoke. The protracted debate on this will not be reproduced here. Only the Tattvārtha-sütra is being quoted for the Jaina position: TAS 1, 20: śrutam mati-pūrvam dvy-aneka-dvādaśa-bhedam "Scriptural knowledge, preceded by sensory knowledge, is of two kinds, which are of twelve and many subdivisions". This sütra refers to the precedence of sense perception (reading or listening) so that the points mentioned above about matijñana would apply to scriptural or authoritative knowledge. The actual grasping of the authoritative teaching is an internal process, after the senses have performed their functions. The question of the occurrence of error in our cognition is a topic for a separate study (see Soni 2018, especially pp. 51-65).

\section{Manaḥ-paryaya-jñāna}

The changed mode of manas in the form of manah-paryaya is direct (by definition) and we saw how manas is allied to sight which is mati-jñanna, namely indirect.

The five kinds of pramāṇa are listed in TAS 1, 9 and Pūjyapāda's SS commentary on it mentions a point that we can now better understand. It has to do with the specific role of manas and shows an awareness of the concern with how manah-paryaya is different from mati-jñāna. He says there:

parakīya-mano-gato 'rtho mana ity ucyate I sāhacaryāt tasya paryayañam parigamanam manah-paryayah । mati-jñāna-prasanga iti cet; na; apekśāmātratvāt I kṣayopaśama-śakti-mātra-vijṛmbhitam hi tat-kevalam sva-paramanobhir vyapadiśyate I yathā abhre candramasam paśyeti I (SS on TAS 1, 9, $\S 164$, pp. 67-68). ${ }^{26}$

\footnotetext{
${ }^{26}$ See also Tatia (1952, pp. 66-67).
} 
The object connected with the manas of another person is said to be the manas [of the other person]. Manah-paryaya is ascertaining it, encompassing it on account of an association with it. Now, is it mati-jñanna? No, because it (manas) is merely relative (or related to it). That which is displayed by destruction-cum-subsidence alone is merely spoken of with reference to one's own and another's manas, just as we say 'look at the moon in the sky' (here the sky is intended merely as the background) (tr. based on Jain 1960, p. 16).

It is noteworthy that only after many sütras subsequent to TAS 1, 9 which mentions the five pramānas, mati, etc., ${ }^{27}$ do we learn that three of them mati, śruta, and avadhi can or may be erroneous as well (TAS 1, 31/32: mati-śruta-avadhayo viparyayaś ca), not manah-paryaya and kevala! This means that we have to re-read TAS 1,9 in the light of TAS $1,31 / 32$ in order to arrive at a proper view of Jaina epistemology and the theory of error couched in it. The point is noteworthy because of the special status given to manah-paryaya (and kevala). Since they are defined as not being erroneous they are a reliable source of cognition or knowledge for the Jainas. As already said manah-paryaya as a means of knowledge presupposes an advanced stage of asceticism, one that is not affected by the karma that usually hinders the function of manah-paryāya in ordinary individuals. It is in view of this that TAS 1,23/24 says that the differences between the two kinds of manah-paryaya $(\text { rju-vipulamatī manah-paryayah })^{28}$ are due only to the degree of purity (e.g., whether the corresponding karmic veil has subsided and not completely removed) and infallibility (TAS 1, 24/25: viśuddhy-apratipātābhyām tad-viśeșah).

Returning now again to Sānkhya, we saw that cognition through the senses is a split-second, complex process that involves the roles of buddhi, ahamkāra, manas and the indriyas. We saw that manas has the unique status of being both a buddhindriya as well as a karmendriya (SK 26-27). This function of manas as a buddhindriya in Sānkhya is clearly related to the role of buddhi that is explicitly stated as being determinative in SK 23, namely to finally determine what the object is and that this function operates optimally when the sattva component predominates. $^{29}$ To consciously train manas as a buddhindriya for an operation with an optimum of sattva presupposes a special training involving a clear understanding of the difference between purușa and prakrti (as in Yoga). Now, in view of the fact that in Jainism manah-paryaya-jñāna also presupposes, as we saw, an advanced

\footnotetext{
${ }^{27}$ To repeat TAS 1, 9 here for the context, the Jaina pramānas are: mati (sense perception), śruta (scriptural or authoritative source of knowledge), avadhi (clairvoyance), manah-paryaya (telepathy or communicating without the use of the senses, also written manah-paryaya) and kevala (omniscience).

${ }^{28}$ In his commentary to TAS 1, 24/25 Pūjyapāda says that vipulamati is purer than rijumati, § 220: tatra viśuddhyā tāvat - rju-mater vipulamatir dravya-kșetra-kāla-bhāvair viśuddhatarah | "First with regard to purity. Vipulamati is purer than rjumati with regard to the object (subject matter), space, time and nature or condition" (tr. Jain 1960, p. 35). See also the statement that "rjumati undergoes downfall or deterioration, as its possessor is of the descending order owing to the rise of passions", ibid., 36 and other technical details regarding the two kinds of manah-paryaya.

${ }^{29}$ SK 23: adhyavasāyo buddhir dharmo jñānam virāga aiśvaryam | sātvikam etad-rūpam tāmasam asmād viparyastam II "Intellect is determinative. Virtue, wisdom, non-attachment, the possession of lordly powers constitute its sātvika form (i.e., its form when the constituent Sattva, goodness, predominates); the reverse of these are its tāmasa form (i.e., of its nature, when Tamas, darkness, predominates)" tr. Sastri (1935, p. 56).
} 
stage of asceticism, I submit that in this particular context manah-paryaya can be understood in comparison with the role of manas as a buddhīndriya in Sānkhya that operates ideally with the predominance of sattva-guṇa. In both Jainism and Sānkhya an advanced stage of development obtained through ascetic discipline is presupposed, making a comparison of the case in point plausible.

\section{Conclusion}

It was seen that the term manas in Jainism can be traced back to so-called groups (varganā/vaggan $\bar{a}$ ) of matter (pudgala). The ȘkhĀ gives a list of five such groups, of which manas is one. Moreover, four kinds of manas-groups, namely manas groups of matter (mana-davva-vaggana) are given in $\operatorname{S} k h \bar{A} ~ 5,6,750-751$. Furthermore, matter was seen seen as being constituted of atoms and molecules (TAS 5, 25) with their aggregation (samghāta) and disjunction (bjeda) mentioned in TAS 5, 26 and 28. It was also seen that while Umāsvāti does not use the term varganāa/vaggan $\bar{a}$ he nonetheless retains the idea of atoms and molecules aggregating and/or disjoining.

The role of the manas was seen in mati (sense perception), śruta (scriptural or authoritative source of knowledge), and manah-paryaya (telepathy or communicating without the use of the senses (also written manah-paryaya), omitting the remaining two means of cognition accepted by the Jainas, avadhi (clairvoyance) and kevala (omniscience), for the reasons already given. In the case of mati the perceptive Jaina view was briefly touched upon, namely of regarding sight (and manas) as being different from the other four sense perceptions through touch, taste, smell and hearing, because the objects of sight do not 'enter, touch or are in direct contact with the eyes', as is the case with the perception through touch, etc. The modified form of manas in its function as manah-paryaya was also briefly discussed in order to show its difference from mati. Mati also plays a role in śruta, without the latter means of cognition being reduced to sense perception on account of the involvement of hearing or reading.

It is well-known in the Indian context that each school accepts its own number with regard to the means of cognition. It is assumed that there were logical criteria for accepting specific types of pramānas. It seems that there are at least four general conditions or criteria for the accepted number of the means of cognition in all the schools, which the Jainas also implicitly accepted. These criteria can be summarised in conclusion as follows:

1. The cognition that each means of cognition or knowledge furnishes must be new and not attainable by any other means.

2. One means of cognition may aid another in making cognition possible, for example perception may aid the cognition arrived at through an inference, e.g. inferring the seen smoke from the unseen fire, but the means in question should not be reducible to another. In Jainism authoritative statements (śruta) cannot be reduced to sense perception (mati), although hearing or reading plays a role, as we saw. 
3. The cognition arrived at through a particular means should not be contradicted (abādhita) by another means.

4. The accepted means of cognition should appeal to reason and in the case of scriptural or trustworthy authority (śabda, śruti or śruta), for example, the truth that is revealed must appear probable and be made intelligible in terms of human experience, otherwise the revealed truth would fail in its purpose of being understandable and thereby become useless (see also Soni 1989, p. 119).

Acknowledgements Open access funding provided by University of Innsbruck and Medical University of Innsbruck.

Open Access This article is licensed under a Creative Commons Attribution 4.0 International License, which permits use, sharing, adaptation, distribution and reproduction in any medium or format, as long as you give appropriate credit to the original author(s) and the source, provide a link to the Creative Commons licence, and indicate if changes were made. The images or other third party material in this article are included in the article's Creative Commons licence, unless indicated otherwise in a credit line to the material. If material is not included in the article's Creative Commons licence and your intended use is not permitted by statutory regulation or exceeds the permitted use, you will need to obtain permission directly from the copyright holder. To view a copy of this licence, visit http:// creativecommons.org/licenses/by/4.0/.

\section{Abbreviations and Literature}

Dundas, P. (2002). The Jains. London and New York: Routledge.

Jain (1960). see Pūjyapāda.

Jaini, P. S. (1979). The Jaina path of purification. Delhi: Motilal Banarsidass.

Kalghatgi, T. G. (1991). The concept of mind in Jainism. In M. A. Dhaky, \& S. Jain (Eds.), Aspects of Jainology Vol. III Pt. Dalsukh Bhai Malvania Felicitation Volume I (pp. 125-130). Varanasi: P.V. Research Institute.

Kobayashi, H. (2010). Self-awareness and mental perception. Journal of Indian Philosophy,38, 233-245. Oberlies, T. (1993). Āvaśyaka-Studien. Glossar augewählter Wörter zu E. Leumann's “Die ĀvaśyakaErzählungen. Stuttgart: Franz.

Pūjyapāda: Sarvārtha-siddhi [śrīmad-ācārya-gṛddhapiccha-praṇītasya tattvārtha-sūtrasya vrttih]. Dillī: Bhāratīya Jñānapīṭa Prakāśana (1991 fifth ed.). Translated by S.A. Jain as Reality. English Translation of Shri. Pujyapada's Sarvarthasiddhi. Madras: Jwalamalini Trust (originally published in 1960 in Calcutta: Vira Sasana Sangha). (See also Tatia 1994.)

Puṣpadanta and Bhūtabali (ca. 2nd c. CE), 1992-1995 ed., Șațkhạ̣dāgama with Vīrasen's Dhavalā-țikā and Hindi tr. in 16 volumes. Solāpura: Jaina Saṃskriti Saṃrakṣaka Sañgha.

Sastri, S. S. S. (Ed. and Trans.) (1935). The Sān்khyakārikā of İśvara Kṛṣna. Madras: University of Madras (publication of the Department of Indian Philosophy, No. 3).

Shastri, I. C. (1990). Jaina epistemology. Varanasi: P.V. Research Institute.

SK = Sāṅkhya-kārikā by Íśvarakṛ̦ṇa. See Sastri 1935.

ȘkhĀ: Saṭhaṇ̂̄āgama, see Puṣpadanta and Bhūtabali.

SS: Sarvārtha-siddhi, commentary of the TAS. See Pūjyapāda.

Soni, J. (1989). Philosophical anthropology in Śaiva Siddhānta. With special reference to Śivāgrayogin. Delhi: Motilal Banarsidass (2018).

Soni, J. (1991). Dravya, Guna and Paryāya in Jaina Thought. Journal of Indian Philosophy, 19, 75-88.

Soni, J. (2007). Upayoga, according to Kundakunda and Umāsvāti. Journal of Indian Philosophy,35, 299311.

Soni, J. (2015). Aspects of philosophy in the Sațhaṇāgama. In P. Flügel \& O. Qvarnström (Eds.), Jaina scriptures and philosophy (pp. 133-144). London: Routledge.

Soni, J. (2016). Yoga in the Tattvārthasūtra. In C. K. Chapple (Ed.), Yoga in Jainism (pp. 29-36). London: Routledge. 
Soni, J. (2018). Jaina epistemology. Including the Jaina theory of error. New Delhi: Aditya Prakashan.

TAS: Umāsvāti's Tattvārtha-sūtra.

Tatia, N. (1951). Studies in Jaina philosophy. Varanasi: P.V. Research Institute.

Tatia, N. (1994). Tattvārthasūtra. That Which Is. Umāsvāti/Umāsvāmī with the combined commentaries of Umāsvāti/Umāsvāmī, Pūjyapāda and Siddhasenagani. Translated with an introduction. San Francisco: HarperCollins Publishers.

Umāsvāti (ca. 5th c.):

1991 ed.: Tattvārtha-sūtra. The Digambara commentary is quoted from Pūjyapāda's SS above. See also Jain 1960.

1932 Śvetāmbara ed.: Sabhāșyatattvārthādhigamasūtra, Bambaī: Maṇīlāla, Revāśaṃkara Jagajivana Jhaverī. See also Tatia 1994.

Varṇī, J. (1990). Jainendra Siddhaanta Kośa (5 Vols). Third edition 1990-1993. Delhi: Bhāra-tīya Jñānapītha.

Wiley, K. L. (2003). Extrasensory perception and knowledge in Jainism. In P. Balcerowicz (Ed.), Caturaranayacakram: Essays in Jaina philosophy and religion (pp. 89-109). Delhi: Motilal Banarsidass.

Publisher's Note Springer Nature remains neutral with regard to jurisdictional claims in published maps and institutional affiliations. 